\title{
Jiangella alba sp. nov., an endophytic actinomycete isolated from the stem of Maytenus austroyunnanensis
}

\author{
Sheng Qin, Guo-Zhen Zhao, Jie Li, Wen-Yong Zhu, Li-Hua Xu \\ and Wen-Jun Li
}

\author{
Correspondence \\ Wen-Jun Li \\ wjli@ynu.edu.cn \\ or \\ liact@hotmail.com
}

\author{
The Key Laboratory for Microbial Resources of the Ministry of Education, PR China, and Laboratory \\ for Conservation and Utilization of Bio-resources, Yunnan Institute of Microbiology, Yunnan \\ University, Kunming, Yunnan 650091, PR China
}

The genus Jiangella was proposed by Song et al. (2005) to accommodate an aerobic, Gram-positive actinomycete with LL-2,6-diaminopimelic acid (LL-DAP) in the cell-wall peptidoglycan and MK-9 $\left(\mathrm{H}_{4}\right)$ as the predominant menaquinone. At present, this genus comprises only two species, Jiangella gansuensis (Song et al., 2005) and Jiangella alkaliphila (Lee, 2008), which were both isolated from soil samples. In this paper, we describe the polyphasic characterization of strain YIM $61503^{\mathrm{T}}$ isolated from an endophytic environment.

Strain YIM $61503^{\mathrm{T}}$ was isolated from the healthy stem of a traditional Chinese medicinal plant, Maytenus austroyunnanensis, collected from a tropical rainforest in Xishuangbanna, Yunnan Province, south-west China. Stem samples were air-dried at room temperature after being thoroughly washed under tap water and surface sterilized according to the five-step sterilization procedure (Qin et al., 2008). Samples were then pulverized in a

Abbreviation: DAP, 2,6-diaminopimelic acid.

The GenBank/EMBL/DDBJ accession number for the $16 \mathrm{~S}$ rRNA gene sequence of strain YIM $61503^{\top}$ is FJ157186.

A supplementary table showing the cellular fatty acid profiles of type strains of the genus Jiangella is available with the online version of this paper. ceramic mortar and processed with a calcium carbonate enrichment method described by Otoguro et al. (2001). The samples were serially diluted in sterile distilled water and spread-plated on glycerol-asparagine agar (ISP 5) (Shirling \& Gottlieb, 1966). Strain YIM $61503^{\mathrm{T}}$ was isolated after incubation at $28{ }^{\circ} \mathrm{C}$ for 21 days and was subsequently maintained as mycelial fragments in a $20 \%(\mathrm{v} / \mathrm{v})$ glycerol suspension at $-80{ }^{\circ} \mathrm{C}$.

Extraction of genomic DNA and amplification of the $16 \mathrm{~S}$ rRNA gene were done as described by Li et al. (2007). The almost-complete 16S rRNA gene sequence of strain YIM $61503^{\mathrm{T}}$ (1519 bases) was aligned using the CLUSTAL $\mathrm{X}$ program (Thompson et al., 1997) with the 16S rRNA gene sequences of closely related strains retrieved from the GenBank database. Phylogenetic trees were constructed using the neighbour-joining (Saitou \& Nei, 1987) and maximum-parsimony (Kluge \& Farris, 1969) methods with the software package MEGA 3.1 (Kumar et al., 2004); distances between sequences were calculated using Kimura's two-parameter model (Kimura, 1980). A bootstrap analysis was performed to assess the confidence limits of the branching (Felsenstein, 1985).

DNA-DNA hybridization was performed using the fluorometric microwell method (Ezaki et al., 1989) with the 
modifications described by $\mathrm{He}$ et al. (2005). The G+C content of the genomic DNA was determined using the HPLC method as described by Mesbah et al. (1989).

Determination of morphological traits and colour of the aerial and substrate mycelium, as well as of soluble pigments, was done as described by Shirling \& Gottlieb (1966). Cell morphological characteristics were observed by using light microscopy (BH2; Olympus) and scanning electron microscopy (JSM5600LV; JEOL) after 30 days' growth on ISP 2 medium. Determination of growth at different temperatures $(0,4,10,15,20,28,37,40,45$ and $\left.55{ }^{\circ} \mathrm{C}\right)$ and $\mathrm{pH}(\mathrm{pH} 4.0-11.0$ at intervals of $0.5 \mathrm{pH}$ units) and tolerance of $\mathrm{NaCl}(0-15 \%, \mathrm{w} / \mathrm{v}$, at intervals of $0.5 \%)$ were performed using ISP 2 as basal medium. Other physiological and biochemical characteristics of strain YIM $61503^{\mathrm{T}}$ were examined by using standard procedures (Gordon et al., 1974).

For most chemotaxonomic analyses, strain YIM $61503^{\mathrm{T}}$ was grown in yeast extract-malt extract broth in flasks on a rotary shaker at 170 r.p.m. at $28{ }^{\circ} \mathrm{C}$. Biomass for quantitative fatty acid analysis was prepared by using cells grown in nutrient broth at $30{ }^{\circ} \mathrm{C}$ for 3 days, with shaking at 170 r.p.m. Fatty acids were analysed according to the standard protocol of the Microbial Identification System (Sasser, 1990; Kämpfer \& Kroppenstedt, 1996). Analyses of amino acids and sugars were carried out using the methods of Hasegawa et al. (1983). Menaquinones were extracted and purified as described by Collins et al. (1977) and analysed by HPLC (Groth et al., 1997). Phospholipids were extracted and identified by two-dimensional TLC (Minnikin et al., 1979; Collins \& Jones, 1980). Mycolic acids were determined using the method of Minnikin et al. (1980).

The results of the phylogenetic analysis (Fig. 1) revealed that strain YIM $61503^{\mathrm{T}}$ formed a separate line of descent in the phylogenetic cluster of the genus Jiangella. 16S rRNA gene sequence similarities between strain YIM $61503^{\mathrm{T}}$ and J. alkaliphila $\mathrm{D} 8-87^{\mathrm{T}}$ and J. gansuensis YIM $002^{\mathrm{T}}$ were 98.8 and $98.6 \%$, respectively. Hybridization experiments revealed that the DNA-DNA relatedness between strain YIM $61503^{\mathrm{T}}$ and J. alkaliphila DSM $45079^{\mathrm{T}}(45.3 \%)$ and $J$. gansuensis YIM $002^{\mathrm{T}}(41 \%)$ was well below the $70 \%$ cutoff point generally recognized for genomic species (Stackebrandt \& Goebel, 1994), which suggests that this strain should be considered as representing a novel species.

Strain YIM $61503^{\mathrm{T}}$ exhibited good growth on ISP 2, ISP 4 , potato dextrose agar, Czapek's agar and nutrient agar and moderate growth on ISP 3 and ISP 5 agar. White aerial mycelium and yellowish-white to orange-yellow substrate mycelium were formed on the media tested. Both aerial and substrate mycelia fragmented into short or elongated rods (Fig. 2). No diffusible pigments were observed. Strain YIM $61503^{\mathrm{T}}$ grew in the presence of up to $10 \% \mathrm{NaCl}$. The optimal temperature and $\mathrm{pH}$ for growth were $28{ }^{\circ} \mathrm{C}$ and pH 7.0-8.0. Strain YIM $61503^{\mathrm{T}}$ differs substantially from $J$. alkaliphila DSM $45079^{\mathrm{T}}$ and J. gansuensis YIM $002^{\mathrm{T}}$ in terms of phenotypic characteristics (Table 1). Detailed phenotypic characteristics are presented in the species description.

Most of the chemotaxonomic data confirmed that strain YIM $61503^{\mathrm{T}}$ belongs to the genus Jiangella. The cell-wall peptidoglycan contained LL-DAP as the diagnostic diamino acid. The whole-cell sugars comprised glucose, ribose and galactose. The predominant menaquinone was MK-9 $\left(\mathrm{H}_{4}\right)$ (92.8\%), with MK-9 $\left(\mathrm{H}_{2}\right)(5.2 \%)$ and MK-9 $\left(\mathrm{H}_{6}\right)(2.0 \%)$ as minor components. The phospholipid profile comprised diphosphatidylglycerol, phosphatidylglycerol, phosphatidylinositol, phosphatidylinositol mannosides and some unknown phosphoglycolipids and phospholipids, which was somewhat different from that of J. alkaliphila DSM

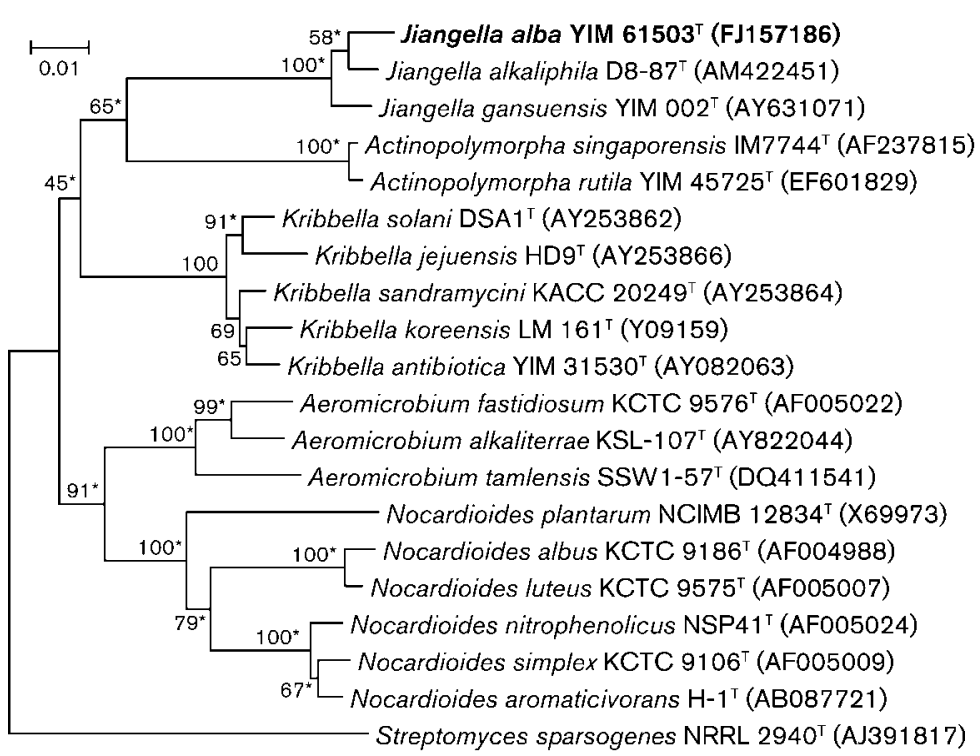

Fig. 1. Neighbour-joining phylogenetic tree based on 16S rRNA gene sequences showing the positions of strain YIM $61503^{\top}$ and some related taxa. Percentages at nodes are levels of bootstrap support based on 1000 resamplings. Asterisks indicate nodes recovered in a phylogenetic tree constructed with the maximum-parsimony method. The sequence of Streptomyces sparsogenes NRRL $2940^{\top}$ was used as the outgroup. Bar, 0.01 substitutions per nucleotide position. 


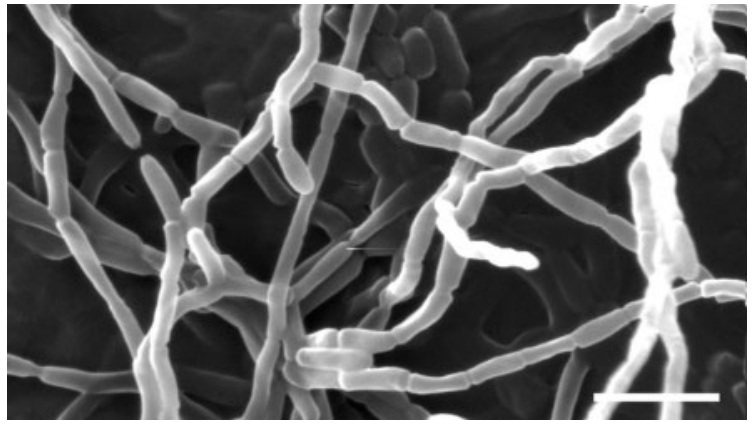

Fig. 2. Scanning electron micrograph of growth of strain YIM $61503^{\top}$ cultivated on ISP 2 medium for 30 days at $28^{\circ} \mathrm{C}$. Bar, $2 \mu \mathrm{m}$.

$45079^{\mathrm{T}}$ in that phosphatidylcholine was not detected. Mycolic acids were not present. The major fatty acids were anteiso- $\mathrm{C}_{15: 0} \quad(26.1 \%)$, iso- $\mathrm{C}_{16: 0} \quad(20.6 \%)$, iso- $\mathrm{C}_{14: 0}$ $(10.0 \%), \mathrm{C}_{17: 1} \omega 8 c(9.8 \%)$ and anteiso- $\mathrm{C}_{17: 0}(8.2 \%)$. This fatty acid profile is similar to those of the two recognized Jiangella species, although there are differences in the proportions of some fatty acids. A detailed comparison of the fatty acid profiles is given in Supplementary Table S1 (available in IJSEM Online).

On the basis of the genotypic and phenotypic data, strain YIM $61503^{\mathrm{T}}$ is clearly distinguished from its phylogenetically closest relatives. Therefore, strain YIM $61503^{\mathrm{T}}$ represents a novel species of the genus Jiangella, for which we propose the name Jiangella alba sp. nov.

\section{Description of Jiangella alba sp. nov.}

Jiangella alba ( $\mathrm{al}$ 'ba. L. fem. adj. alba white, referring to the white aerial hyphae).

Aerobic, Gram-positive-staining, non-acid-alcohol-fast actinomycete. Grows at $15-45{ }^{\circ} \mathrm{C}$ (optimum $28{ }^{\circ} \mathrm{C}$ ) and $\mathrm{pH}$ 6.5-9.0 (optimum pH 7.0). Grows in the presence of $10 \% \mathrm{NaCl}$. Forms well-developed white aerial mycelium and yellowish-white to orange-yellow substrate mycelium that fragment into short or elongated rods. No diffusible pigment is produced on any of the media tested. Adenine, casein, hypoxanthine and xanthine are degraded, but chitin, starch, DL-tyrosine and urea are not. Positive for catalase production, gelatin liquefaction and nitrate reduction, but negative for milk coagulation and peptonization, cellulose hydrolysis and $\mathrm{H}_{2} \mathrm{~S}$ production. Positive for utilization of D- and L-arabinose, meso-erythritol, Dfructose, D-glucose, glycerol, inulin, maltose, D-mannitol, D-mannose, melezitose, raffinose, L-rhamnose, D-ribose, salicin, sucrose, trehalose and D-xylose as sole carbon and energy sources. Negative for utilization of acetate, adonitol, cellobiose, citrate, D-dulcitol, formate, D-galactose, myoinositol, lactose, malate, methyl $\alpha$-D-mannoside, D-sorbitol, L-sorbose and D-xylitol. The cell wall contains LL-DAP. The whole-cell sugars are glucose, ribose and galactose. The
Table 1. Differential characteristics between Jiangella alba sp. nov. YIM $61503^{\top}$ and other type strains of the genus Jiangella

Strains: 1, YIM $61503^{\mathrm{T}}$; 2, J. alkaliphila D8 $-87^{\mathrm{T}}$ (data from Lee, 2008); 3, J. gansuensis YIM $002^{\mathrm{T}}$ (Song et al., 2005). All strains utilized Dand L-arabinose, D-fructose, D-glucose, glycerol, inulin, maltose, Dmannitol, D-mannose, L-rhamnose, sucrose and D-xylose as sole carbon and energy sources, but not methyl $\alpha$-D-mannoside, L-sorbose, D-dulcitol, formate or malate. All strains degraded casein and liquefied gelatin, but did not degrade chitin, starch or DL-tyrosine or produce $\mathrm{H}_{2} \mathrm{~S}$.

\begin{tabular}{|c|c|c|c|}
\hline Characteristic & 1 & 2 & 3 \\
\hline \multicolumn{4}{|l|}{ Growth at/with: } \\
\hline $5 \% \mathrm{NaCl}$ & + & - & + \\
\hline $\mathrm{pH} 10.0$ & - & + & + \\
\hline $45^{\circ} \mathrm{C}$ & + & - & - \\
\hline \multicolumn{4}{|l|}{ Utilization of: } \\
\hline Acetate & - & - & + \\
\hline Adonitol & - & + & + \\
\hline Cellobiose & - & + & + \\
\hline Citrate & - & - & + \\
\hline meso-Erythritol & + & - & - \\
\hline D-Galactose & - & - & + \\
\hline myo-Inositol & - & - & + \\
\hline Lactose & - & + & + \\
\hline D-Mannitol & + & + & - \\
\hline Melezitose & + & - & + \\
\hline Raffinose & + & - & - \\
\hline D-Ribose & + & - & - \\
\hline Salicin & + & - & + \\
\hline D-Sorbitol & - & - & + \\
\hline Trehalose & + & - & + \\
\hline D-Xylitol & - & - & + \\
\hline \multicolumn{4}{|l|}{ Degradation of: } \\
\hline Urea & - & - & + \\
\hline Hypoxanthine & + & + & - \\
\hline Xanthine & + & - & - \\
\hline Reduction of nitrate & + & - & - \\
\hline $\mathrm{G}+\mathrm{C}$ content $(\mathrm{mol} \%)$ & 71.9 & 71.5 & 70 \\
\hline
\end{tabular}

predominant menaquinone is MK-9 $\left(\mathrm{H}_{4}\right)$. Major fatty acids $(>5 \%)$ are anteiso- $\mathrm{C}_{15: 0}$, iso- $\mathrm{C}_{16: 0}$, iso- $\mathrm{C}_{14: 0}, \mathrm{C}_{17: 1} \omega 8 c$, anteiso- $\mathrm{C}_{17: 0}$ and iso- $\mathrm{C}_{15: 0}$. The DNA G $+\mathrm{C}$ content of the type strain is $71.9 \mathrm{~mol} \%$.

The type strain, YIM $61503^{\mathrm{T}}\left(=\right.$ DSM $45237^{\mathrm{T}}=$ CCTCC AA $208023^{\mathrm{T}}$ ), was isolated from surface-sterilized stems of Maytenus austroyunnanensis collected from a tropical rainforest of Xishuangbanna, Yunnan Province, south-west China.

\section{Acknowledgements}

The authors are grateful to Professor Hans-Peter Klenk for kindly providing J. alkaliphila DSM $45079^{\mathrm{T}}$. This research was supported by the National Basic Research Program of China (project no. 2004CB719601), the Yunnan Provincial International Cooperative Program (no. 2005GH21), the Key Project of Chinese Ministry of 
Education (no. 206139) and the National Natural Science Foundation of China (project nos 30600001, 30870005). W.-J. L. was supported by the Program for New Century Excellent Talents in University. The authors are indebted to Jing Xiao for the analysis of cellular fatty acids and Yun Chen for determination of DNA G + C content.

\section{References}

Collins, M. D. \& Jones, D. (1980). Lipids in the classification and identification of coryneform bacteria containing peptidoglycans based on 2,4-diaminobutyric acid. J Appl Bacteriol 48, 459-470.

Collins, M. D., Pirouz, T., Goodfellow, M. \& Minnikin, D. E. (1977). Distribution of menaquinones in actinomycetes and corynebacteria. J Gen Microbiol 100, 221-230.

Ezaki, T., Hashimoto, Y. \& Yabuuchi, E. (1989). Fluorometric deoxyribonucleic acid-deoxyribonucleic acid hybridization in microdilution wells as an alternative to membrane filter hybridization in which radioisotopes are used to determine genetic relatedness among bacterial strains. Int J Syst Bacteriol 39, 224-229.

Felsenstein, J. (1985). Confidence limits on phylogenies: an approach using the bootstrap. Evolution 39, 783-791.

Gordon, R. E., Barnett, D. A., Handerhan, J. E. \& Pang, C. H.-N. (1974). Nocardia coeliaca, Nocardia autotrophica, and the nocardin strain. Int J Syst Bacteriol 24, 54-63.

Groth, I., Schumann, P., Rainey, F. A., Martin, K., Schuetze, B. \& Augsten, K. (1997). Demetria terragena gen. nov., sp. nov., a new genus of actinomycetes isolated from compost soil. Int J Syst Bacteriol 47, 1129-1133.

Hasegawa, T., Takizawa, M. \& Tanida, S. (1983). A rapid analysis for chemical grouping of aerobic actinomycetes. J Gen Appl Microbiol 29, 319-322.

He, L., Li, W., Huang, Y., Wang, L., Liu, Z., Lanoot, B., Vancanneyt, M. \& Swings, J. (2005). Streptomyces jietaisiensis sp. nov., isolated from soil in northern China. Int J Syst Evol Microbiol 55, 1939-1944.

Kämpfer, P. \& Kroppenstedt, R. M. (1996). Numerical analysis of fatty acid patterns of coryneform bacteria and related taxa. Can J Microbiol 42, 989-1005.

Kimura, M. (1980). A simple method for estimating evolutionary rates of base substitutions through comparative studies of nucleotide sequences. J Mol Evol 16, 111-120.

Kluge, A. G. \& Farris, J. S. (1969). Quantitative phyletics and the evolution of anurans. Syst Zool 18, 1-32.

Kumar, S., Tamura, K. \& Nei, M. (2004). MEGA3: integrated software for molecular evolutionary genetics analysis and sequence alignment. Brief Bioinform 5, 150-163.
Lee, S. D. (2008). Jiangella alkaliphila sp. nov., an actinobacterium isolated from a cave. Int J Syst Evol Microbiol 58, 1176-1179.

Li, W. J., Xu, P., Schumann, P., Zhang, Y. Q., Pukall, R., Xu, L. H., Stackebrandt, E. \& Jiang, C. L. (2007). Georgenia ruanii sp. nov., a novel actinobacterium isolated from forest soil in Yunnan (China), and emended description of the genus Georgenia. Int J Syst Evol Microbiol 57, 1424-1428.

Mesbah, M., Premachandran, U. \& Whitman, W. B. (1989). Precise measurement of the $\mathrm{G}+\mathrm{C}$ content of deoxyribonucleic acid by high-performance liquid chromatography. Int J Syst Bacteriol 39, 159-167.

Minnikin, D. E., Collins, M. D. \& Goodfellow, M. (1979). Fatty acid and polar lipid composition in the classification of Cellulomonas, Oerskovia and related taxa. J Appl Bacteriol 47, 87-95.

Minnikin, D. E., Hutchinson, I. G., Caldicott, A. B. \& Goodfellow, M. (1980). Thin layer chromatography of methanolysates of mycolic acid-containing bacteria. J Chromatogr 188, 221-233.

Otoguro, M., Hayakawa, M., Yamazaki, T. \& limura, Y. (2001). An integrated method for the enrichment and selective isolation of Actinokineospora spp. in soil and plant litter. J Appl Microbiol 91, 118-130.

Qin, S., Wang, H. B., Chen, H. H., Zhang, Y. Q., Jiang, C. L., Xu, L. H. \& Li, W. J. (2008). Glycomyces endophyticus sp. nov., an endophytic actinomycete isolated from the root of Carex baccans Nees. Int J Syst Evol Microbiol 58, 2525-2528.

Saitou, N. \& Nei, M. (1987). The neighbor-joining method: a new method for reconstructing phylogenetic trees. Mol Biol Evol 4, 406425 .

Sasser, M. (1990). Identification of bacteria by gas chromatography of cellular fatty acids, MIDI Technical Note 101. Newark, DE: MIDI Inc.

Shirling, E. B. \& Gottlieb, D. (1966). Methods for characterization of Streptomyces species. Int J Syst Bacteriol 16, 313-340.

Song, L., Li, W. J., Wang, O. L., Chen, G. Z., Zhang, Y. S. \& Xu, L. H. (2005). Jiangella gangsuensis gen. nov., sp. nov., a novel actinomycete from a desert soil in north-west China. Int J Syst Evol Microbiol 55, 881-884.

Stackebrandt, E. \& Goebel, B. M. (1994). Taxonomic note: a place for DNA-DNA reassociation and $16 \mathrm{~S}$ rRNA sequence analysis in the present species definition in bacteriology. Int J Syst Bacteriol 44, 846849.

Thompson, J. D., Gibson, T. J., Plewniak, F., Jeanmougin, F. \& Higgins, D. G. (1997). The CLUSTAL_X windows interface: flexible strategies for multiple sequence alignment aided by quality analysis tools. Nucleic Acids Res 25, 4876-4882. 